\title{
JAMES COOK AND MACARONESIAN BOTANY: TYPIFICATION AND NOMENCLATURE UPDATES OF THE NEW SPECIES DESCRIBED BY JOHANN R. FORSTER AND J. GEORG A. FORSTER
}

\author{
Javier Francisco-Ortega*, Kanchi N. Gandhi**, \\ Maria Cristina Duarte***, Arnoldo Santos-Guerra ${ }^{\vartheta}$, \\ Mark A. Carine ${ }^{\diamond \diamond} \&$ Maria M. Romeiras ${ }^{\diamond \diamond \diamond}$
}

\section{Abstract}

Johann Reinhold Forster and his teenaged son John Georg Adam Forster (then 17) joined James Cook's second voyage (1772-1775), as botanist and artist, respectively. Upon their return they described six species that are pertinent to the study of the Macaronesian flora. Previous typifications are revisited and we designate lectotypes for Aytonia rupestris J.R. Forst. \& G. Forst. (Aytoniaceae), Borago tristis G. Forst. (Boraginaceae), and Teucrium canescens G. Forst. (Lamiaceae). We designate epitypes for A. rupestris and Epibaterium pendulum J.R. Forst \& G. Forst. Our study indicates that Teucrium betonicifolium Jacq. is the accepted name for this Madeiran endemic. Lectotypes, along with epitypes, are also designated for T. betonicifolium and T. betonicum L'Hér.

KeYwords: botanical history, Atlantic islands, plant taxonomy, botanical exploration, the enlightenment.

JAMES COOK Y LA BOTÁNICA MACARONÉSICA:

NOTAS NOMENCLATURALES DE LAS NUEVAS ESPECIES

DESCRITAS POR JOHANN R. FORSTER AND J. GEORG A. FORSTER

\section{RESUMEN}

Johann Reinhold Forster y su hijo John Georg Adam Forster (entonces con 17 ańos) se unieron, respectivamente como botánico y artista, al segundo viaje de circunnavegación de James Cook (1772-1775). Aquí proporcionamos un estudio nomenclatural de las seis nuevas especies que ellos describieron para la Macaronesia. Se revisan tipificaciones anteriores y designamos lectotipos para Aytonia rupestris J.R. Forst. \& G. Forst. (Aytoniaceae), Borago tristis G. Forst. (Boraginaceae) y Teucrium canescens G. Forst. (Lamiaceae). Designamos epitipos para A. rupestris y Epibaterium pendulum J.R. Forst \& G. Forst. Nuestro estudio indica que Teucrium betonicifolium Jacq. es el nombre que se debe aceptar para este endemismo de Madeira. También se designan lectotipos con epitipos para T. betonicifolium y T. betonicum L'Hér.

Palabras clave: historia de la botánica, islas atlánticas, taxonomía vegetal, exploración botánica, la ilustración. 


\section{INTRODUCTION}

The FloraMac2018 international meeting provided an opportunity to celebrate the $250^{\text {th }}$ anniversary of the visit made by James Cook to the island of Madeira in September 1768 during his famous first voyage aboard HMB Endeavour. During this expedition Cook had the Navy rank of Lieutenant being promoted to Commander in his second circumnavigation voyage (Barlass 2018). Cook was accompanied by the botanist Joseph Banks, who would become one of the great patrons of natural sciences and by Daniel Solander, a disciple of Linnaeus and Assistant Librarian at the British Museum, responsible for cataloguing the natural history collections. From Madeira, the expedition continued to Brazil, Tierra del Fuego, the South Pacific, New Zealand and Australia before returning to The Downs (England) on July 1771 via Java, the Cape and St Helena (Obeyesekere 1992). Two additional extensive oversea voyages led by Cook made visits to Macaronesia: during his second voyage he called at Madeira, Santiago (Cabo Verde), and Faial (Azores); whilst during his third voyage he called at Tenerife (Canaries). The second circumnavigation (17721775) also had a strong botanical component because Johann Reinhold Forster and his son John Georg Adam Forster (then 17) joined the expedition as botanist and artist, respectively (Bodi 1959). Upon their return to Europe, these two German naturalists published many species based on the material that they had collected and recorded during the three-year expedition.

Two of the taxonomic contributions published by the Forsters are important to our research. One of them focused on the many plants that were recorded during the journey [titled as Characteres generum plantarum in Taxonomic Literature 2 (Stafleu and Cowan 1976)] whereas the second work (Forster 1788) provided what we believe was the first published floristic catalogue for Atlantic oceanic islands. This catalogue provided a list of plants that were found on the islands of Ascension, Faial, Madeira, Saint Helena, and Santiago. A bibliographic note regarding the effective publication date of species published in these two contributions is needed.

Characteres generum plantarum was the first book published by the Forsters upon their arrival in Britain (Nicolson and Fosberg 2004; Earp 2013). It had

* International Center for Tropical Botany, Kimberly Green Latin American and Caribbean Center, Cuban Research Institute, Department of Biological Sciences, Florida International University, Miami, Florida. Corresponding author: ortegaj@fiu.edu.

** Harvard University Herbaria, Massachusetts, USA.

*** Centre for Ecology, Evolution and Environmental Changes (cE3c), Faculdade de Ciências, Universidade de Lisboa, Lisboa, Portugal.

$\checkmark$ Calle Guaidil 16, Tegueste, Tenerife, Canary Islands, Spain.

$\checkmark \diamond$ Department of Life Sciences, Natural History Museum, London, United Kingdom.

000 Centre for Ecology, Evolution and Environmental Changes (cE3c), Faculdade de Ciências, Universidade de Lisboa, Lisboa, Portugal. Linking Landscape, Environment, Agriculture and Food (LEAF), Instituto Superior de Agronomia, Universidade de Lisboa, Lisboa, Portugal. Corresponding author: mmromeiras@isa.ulisboa.pt. 
three editions (Forster and Forster 1775, 1776a, 1776b); however, only three copies are known for the 1775 edition (Earp 2013). One of the editions produced in 1776 is known as the "common 1776 quarto edition" (Forster 1776a), the other as the "folio copy" edition (Forster 1776b). The former is also referred as the "Second edition" and it is the most widely distributed one (Stafleu and Cowan 1976). All three 1775-1776 versions are identical with regards their plant plates and the described species (Earp 2013). The last International Botanical Congress (Shenzhen, China) resolved that 1776 is the effective publication date (in the "common 1776 quarto edition") for species published in this book as the 1775 version is only available in three libraries (The Linnean Society of London; the State Library of Victoria, Australia; and the King's Library at the British Library). We follow this decision below.

As originally issued the catalogue of Atlantic island plants, authored by Georg Forster, was published in a work entitled De plantis magellanici et atlanticis commentationes that had two chapters (fig. 1), viz., 1) Fasciculus plantarum magellanicarum (pp. 1-33, t. 1-8), which focused exclusively on those plants that were recorded in Tierra del Fuego; and 2) Plantae Atlanticae ex insulis Madeira St. Jacobi Adscensionis Stae Helenae et Fayal reportatae (pp. 34-62). They also form parts of volume 9 of the journal Commentationes Societatis Regiae Scientiarum Gottingensis (9: 13-74. 1789 (“1787”), fig. 1). There has been conflicting information regarding the date of the publication of the catalogue. Stafleu and Cowan (1976: 859) listed the following in Taxonomic Literature 2:

Fasciculus plantarum magellanicarum... Publ.: 1787 after 18 Sep, date of presentation (see p. 13 of publ. in Comm.), p. [1]-64, pl. 1-8. Copy: M.- Reprinted from Comm. Soc. Goett. 9: 13-74, pl. 1-8.1787 (Copy MO).- The M copy has a t.p. on [1]: "Georgii Forster, M.D. cet. De plantis magellanicis et atlanticis commentationes." This is apparently the special t.p. for the independently paged reprint. The full heading of the journal article (on p. 13) is "Fasciculus plantarum magellanicarum oblatus societati in ipso consessu sollennium Academiae Georgiae augustae semisaecularim d. xviii Sept mdcclxxxvii." This is followed on p. 46 by "Plantae atlanticae ex insulis Madeira, St. Jacobi, Adscensionis, St. Helena et Fayal reportatae.”

Although Stafleu and Cowan (1976: 859) listed the date of publication of this catalogue as "1787 after 18 Sep," the title page and preface of volume 9 show the date as 1789. In contrast, Nicolson and Fosberg (2004: 65) treated Georg Forster's work as a preprint issued in March-April 1788 that was published under the title "De plantis magellanicis et atlanticis commentationes" (fig. 1). Nicolson and Fosberg (2004: 57) mentioned that they had not seen a copy of the preprint; however, they stated the following:

... thanks to Prof. G. Wagenitz (pers. comm.) it is now established that there was a separately paged preprint that appeared between 16-17 Jan 1788, when extant letters from George refer to offprints then being printed, and a 13 May 1788 letter from George that refers to some copies of the offprints accidentally having been left behind in Frankfurt by his servant. It can be presumed that these preprints were distributed by March or April 1788. 


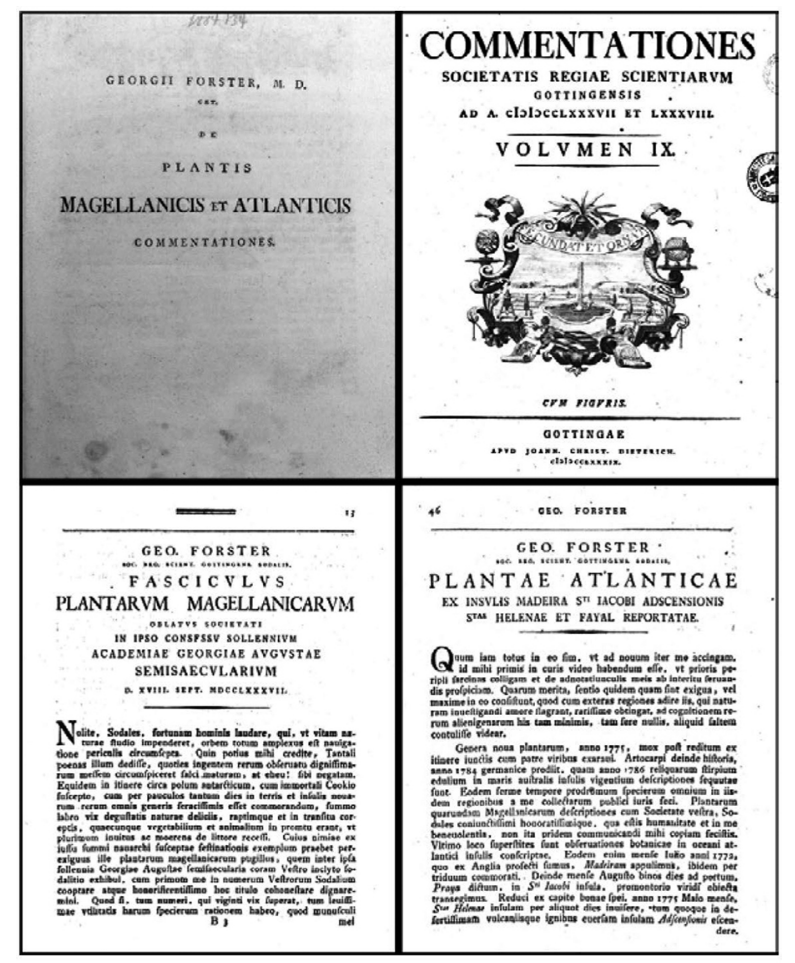

Figure 1. Bibliographic details pertinent to G. Forster's publication on the flora of Atlantic Islands where he described new Macaronesian species for Cabo Verde and Madeira. Top left: Cover of preprint published between March and April 1788 (courtesy of Georg-August-Universität Göttingen, SUB Goettingen, call number: 8 BOTV, 9220). Top right: Cover of volume 9 of Commentationes Societatis Regiae Scientiarum Gottingensis, year 1789. Bottom left: First page of article on Tierra del Fuego plants as it was published in volume 9 of Commentationes Societatis Regiae Scientiarum Gottingensis. Bottom right: First page of article on Atlantic Island plants as it was published in volume 9 of Commentationes Societatis Regiae Scientiarum Gottingensis. Images from volume 9 of Commentationes Societatis Regiae Scientiarum Gottingensis are public domain (https://archive.org/details/bub_gb_BigC_3BYCdMC/page/n4; document provided by the Biblioteca Nazionale Vittorio Emanuele III, Naples).

It is noted here that in the absence of internal evidence, external evidence may be used to determine the date of a publication, and the extant letters from Georg Forster conserved at GOET [herbarium institutions are coded as indicated in Thiers (2019)] serve as such an evidence (cf., Art. 46.9).

Without referencing to Nicolson and Fosberg's (2004: 57) remarks, Dorr and Nicolson (2008: 329) mentioned that "Forster's article was published shortly before 23 May 1789" in Commentationes Societatis Regiae Scientiarum Gottingensis. 
Thus, three different years have been given for species published in this work: 1787 (e.g., Abedin 1979), 1788 (e.g., Nicolson \& Fosberg 2004), and 1789 (e.g., Fryxell 2002). Since the status of "Georgii Forster, M.D. cet. De plantis magellanicis et atlanticis commentationes" as either a preprint (dated 1788) or independently paged reprint (dated 1789) has been disputed, we consulted Dr. Laurence J. Dorr (US). Dorr kinly clarified the situation stating that the serial publication is dated 1789 and that a review indicates that Forster's article was available by 23 May 1789. Furthermore, Dorr suggested that copies of G. Forster's work conserved at Göttingen and Munich need to be examined.

Subsequent requests to Dr. Hans-Joachim Esser (M) and Dr. Marc S. Appelhans (GOET) confirmed the independent pagination of their library copies of "Georgii Forster, M.D. cet. De plantis magellanicis et atlanticis commentationes." However, neither copy has the date of publication or of receipt by the relevant libraries. Dorr (pers. comm.) remarked that although internal evidence for the publication date of the preprint is lacking, there is sufficient external evidence to argue that the names appeared in 1788 (see above). In this regard, Dorr (pers. comm.) concurred with Nicolson and Fosberg (2004: 57) and we accept Dorr's assessment. With reference to Stafleu and Cowan's (1976: 859) treatment of Georg Forster's work as a reprint, we speculate that Stafleu and Cowan erred in believing that the Forster article in the journal (pp. 13-74) was published after 18 September 1787 and eventually as an independently paged "reprint" (pp. 1-64). Obviously, they were not aware that the journal article was published shortly before 23 May 1789 and that the independently paged Forster article could be a preprint published in 1788 .

Among the taxonomic contributions made by the Forsters, there were four new species that were described based on Macaronesian specimens by Georg Forster (1776a, 1788, table 1), one of them was collected in Madeira (Teucrium canescens $\mathrm{G}$. Forst.) and the remaining three came from Cabo Verde (Antirrhinum elegans G. Forst., Borago tristis G. Forst., and Sida pannosa G. Forst.). Furthermore, two additional species (Aytonia rupestris J.R. Forst. \& G. Forst and Epibaterium pendulum J.R. Forst. \& G. Forst) are also relevant to our research. These two species were described by Forster and Forster (1776a) without any precise locality in the three editions of Characteres generum plantarum. An indication of the provenance of Epibaterium pendulum as Santiago, Cabo Verde was, however, provided in two other sources. The first was by Forster (1788), a published account with a long species description; the second was a watercolor made by Georg Forster (housed in BM) that was recently published by Romeiras et al. (2014). Regarding Aytonia rupestris, the only details regarding its distribution was made by Forster (1788) who indicated that this liverwort was found in Madeira in "locis umbrosis humidis, ad saxorum crepidines secundum torrentium decursum." Although, in the original description by Forster and Forster (1776b) it is not stated where these two species were actually located, it is clear from Forster (1788) that they were found in Macaronesia.

Our research provides a nomenclature update for these six species (see table 1 with accepted names) that the Forsters recorded in Macaronesia during Cook's second voyage and subsequently were described by them. 


\begin{tabular}{|c|c|c|c|c|}
\hline \multicolumn{5}{|c|}{$\begin{array}{c}\text { TABLE 1. NATIVE SPECIES FROM MACARONESIA DESCRIBED } \\
\text { BY JOHANN R. FORSTER AND GEORG FORSTER }\end{array}$} \\
\hline $\begin{array}{l}\text { NAME AS ORIGINALLY } \\
\text { PUBLISHED }\end{array}$ & ACCEPTED NAme & FAMILY & ISLAND $^{1}$ & Publication \\
\hline $\begin{array}{l}\text { Antirrhinum elegans } \\
\text { G. Forst. }{ }^{2}\end{array}$ & $\begin{array}{l}\text { Nanorrhinum elegans } \\
\text { (G. Forst.) Ghebr. }\end{array}$ & Plantaginaceae & $\mathrm{CV}$ & Forster (1788) \\
\hline $\begin{array}{l}\text { Aytonia rupestris J.R. } \\
\text { Forst. \& G. Forst. }\end{array}$ & $\begin{array}{l}\text { Plagiochasma rupestre (J.R. } \\
\text { Forst. \& G. Forst.) Steph. }\end{array}$ & Aytoniaceae & M & $\begin{array}{l}\text { Forster and Forster } \\
(1776 \mathrm{a})\end{array}$ \\
\hline Borago tristis G. Forst. & $\begin{array}{l}\text { Trichodesma africanum }(\mathrm{L} .) \\
\text { Lehm }\end{array}$ & Boraginaceae & $\mathrm{CV}$ & Forster (1788) \\
\hline $\begin{array}{l}\text { Epibaterium pendulum } \\
\text { J.R. Forst. \& G. Forst. }\end{array}$ & $\begin{array}{l}\text { Cocculus pendulus (J.R. Forst. } \\
\& \text { G. Forst.) Diels in Engler }\end{array}$ & Menispermaceae & $\mathrm{CV}$ & $\begin{array}{l}\text { Forster and Forster } \\
(1776 \mathrm{a})\end{array}$ \\
\hline Sida pannosa G. Forst. & $\begin{array}{l}\text { Abutilon pannosum } \\
\text { (G. Forst.) Schltdl. }\end{array}$ & Malvaceae & $\mathrm{CV}$ & Forster (1788) \\
\hline $\begin{array}{l}\text { Teucrium canescens } \\
\text { G. Forst. }\end{array}$ & Teucrium betonicifolium Jacq. & Lamiaceae & M & Forster (1788) \\
\hline
\end{tabular}

Nicolson (1998), and Nicolson and Fosberg (2004) catalogued the hundreds of watercolors that Georg Forster made for many of the plants that were recorded or collected along the voyage. This artwork is scattered in seven museums/libraries, and for the most part has remained unpublished. Five of the six species studied in our contribution (i.e., Abutilon pannosum, Cocculus pendulus, Plagiochasma rupestre, Teucrium betonicifolium, and Trichodesma africanum) to this FloraMac2018 special issue were depicted in Forster's paintings and drawings (Romeiras et al. 2014: fig. 7; Francisco-Ortega et al. 2015: figs. 10-14. Reviewed by Romeiras et al. 2014: table 1 and by Francisco-Ortega et al. 2015: table 1). Interestingly, for Aytonia rupestris and Epibaterium pendulum, the illustrations were part of the original species descriptions made by Forster and Forster (1775). In order to further reveal the artwork of Macaronesian plants made by Georg Forster, in our contribution we present copies of his watercolors for Abutilon pannosum (housed in Gotha Library, Thuringia, Germany) and Plagiochasma rupestre (housed in BM). Since the time of their making, both drawings have remained unpublished (see figs. 2-3).

The taxonomic contributions of the Forsters have historical significance as they were the first naturalists to undertake field work in Macaronesia and subsequently publish binomial names for the flora of these islands. Other well-known botanists (e.g., Joseph Banks, João Feijó, Francis Masson, Daniel Solander, James Robertson, George Staunton) collected in the islands during the late $18^{\text {th }}$ century, but none described any species for the region [reviewed by Francisco-Ortega et al. (2010) and Romeiras et al. (2014)]. Daniel Solander prepared a flora for Madeira that remained unpublished as an incomplete manuscript housed at BM (Britten 1904; Francisco-Ortega et al. 2015).

Nicolson and Fosberg (2004) made a remarkable revision pertinent to all known specimens collected by the Forsters during the second voyage of Cook. Their 


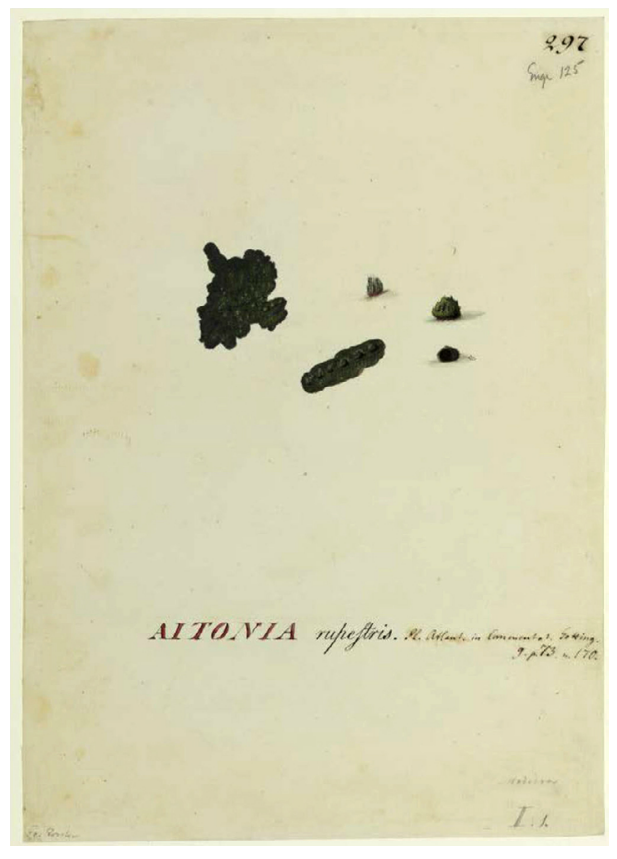

Figure 2. Watercolor of Plagiochasma rupestre (J.R. Forst. \& G. Forst.) Steph. (Aytoniaceae) made by Georg Forster, based on material recorded in Madeira during the second voyage of Cook. Image copyright of the Natural History Museum of London.

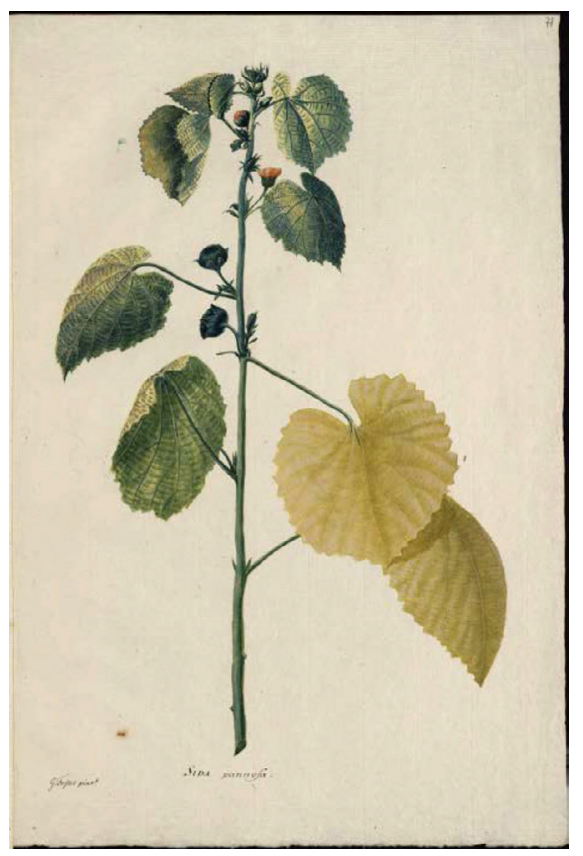

Figure 3. Watercolor of Sida pannosa G. Forst. (Malvaceae) made by Georg Forster, based on material apparently recorded in Cabo Verde Islands during the second voyage of Cook. Image copyright of the Gotha Library, Thuringia, Germany.

work was pivotal for our research as it provided the necessary framework to locate putative type material. Furthermore, Nicolson and Fosberg's (2004) publication also has details regarding typifications previously made for names published by the Forsters. Pertinent to our research, Nicolson and Fosberg (2004) identified typifications that were made for Antirrhinum elegans and Sida pannosa by Sutton (1988) and Abedin (1979), respectively. However, they did not mention the neotypification of Aytonia rupestris performed by Bischler and Sérgio (1984) or the work published by Troupin (1956) in which it was indicated that the holotype of Epibaterium pendulum was identified. Therefore, among the six names that we included in our study only two of them, Borago tristis and Teucrium canescens, were not the subject of any previous typifications.

Here we revisit and update the previous typifications made for Antirrhinum elegans, Aytonia rupestris, Epibaterium pendulum, and Sida pannosa. Furthermore, we designate lectotypes for Borago tristis and Teucrium canescens. We follow the latest International Code of Nomenclature (ICN) for algae, fungi, and plants (the 
Shenzhen code; Turland et al. 2018). The names of the six species included in our study are sorted alphabetically below under the genus in which they were originally described by the Forsters. Accepted names are indicated in bold print. Each of the six nomenclature treatments include "Notes" that have additional discussion. Among these six updates, we lectotypify the three names that apply to the Madeiran endemic T. canescens. As a working taxonomy for accepted names we follow Duarte (1995), Martins (1995), Ghebrehiwet (2000), Fryxell (2002), Klopper et al. (2006), and Sérgio et al. (2006). Designated types are listed in table 2, for most of the types there are images available on the internet, and we provide hyperlinks to the websites that have these images (table 2).

\begin{tabular}{|c|c|c|c|}
\hline $\begin{array}{l}\text { NAME AS ORIGINALly } \\
\text { PUblished }\end{array}$ & LеCTOTYPE $^{1}$ & EрIтуре $^{1}$ & ISOEPITYPE $^{1}$ \\
\hline Antirrhinum elegans $\mathrm{G}$. Forst. & K000411332 & & \\
\hline $\begin{array}{l}\text { Aytonia rupestris J.R. Forst. } \\
\& \text { G. Forst. }\end{array}$ & $\begin{array}{l}\text { Forster and Forster 1776: } \\
\text { Plate } 74\end{array}$ & LISU148993 & $\begin{array}{l}\text { BM013409477; G00121308; } \\
\text { PC771129; PC077134 }\end{array}$ \\
\hline Borago tristis G. Forst. & $\underline{\mathrm{BM} 013399018}$ & & \\
\hline $\begin{array}{l}\text { Epibaterium pendulum J.R. } \\
\text { Forst. \& G. Forst. }\end{array}$ & $\underline{B M 001125013}$ & LISC128987 & BM013731571, A00969309 \\
\hline Sida pannosa G. Forst. & $\underline{B M 000802743}$ & & \\
\hline Teucrium betonicifolium Jacq. & $\begin{array}{l}\text { Jacquin } 1787: \text { T. } 17, \text { Fig. } 2 \\
\text { and illustration of single leaf } \\
\end{array}$ & ORT1057 & \\
\hline Teucrium betonicum L'Hér. & $\underline{B M 013825662}$ & ORT1057 & \\
\hline Teucrium canescens $\mathrm{G}$. Forst. & K001331973 & & \\
\hline
\end{tabular}

\section{THE SIX TYPIFICATION AND NOMENCLATURE UPDATES}

1. Antirrhinum elegans G. Forst., De Plantis Magellanicis et Atlanticis Commentationes: 50, no. 97. Mar-Apr 1788; Commentat. Soc. Regiae Sci. Gott. 9(1): 60, no. 97. 1789 (Plantaginaceae). Kickxia elegans (G. Forst.) D.A. Sutton, Revis. tribe Antirrhineae: 211. 1988. Nanorrbinum elegans (G. Forst.) Ghebrehiwet, Nord. J. Bot. 20: 673. 2000.

Type: "Madeira, in montibus aridis et ad sepes"

Lectotype [designated by Sutton (1988: 212)]: Antirrhinum elegans (Forster) Habitat in Madeira, K (K000411332).

Notes: Nanorrhinum elegans is a Cabo Verde endemic for which the Forsters appear to have made a single collection (see Nicolson and Fosberg 2004). As discussed by Sutton (1988), it seems that labels from different collections were mixed up and material from this species was assigned to the island of Madeira both in the 
protologue ("Madeira, in montibus aridis et ad sepes") and on the label of the actual specimen ("Habitat in Madeira"). This specimen was cited as a "holotype" by Sutton (1988). Since Forster did not refer or indicate a type and since it is uncertain that the protologue of Antirrhinum elegans was based on a single specimen, Sutton's (1988) citation can be regarded as an inadvertent designation of lectotype, as the name was typified before January 1, 2001. Nicolson and Fosberg (2004) were also of the same opinion.

2. Aytonia J.R. Forst. \& G. Forst., Char. Gen. Pl., ed. 2: 147. 1776 (Aytoniaceae), nom. rej. vs. Plagiochasma Lehm. \& Lindenb. 1832 (nom. cons.).

Type: A. rupestris J.R. Forst. \& G. Forst.

Aytonia rupestris J.R. Forst. \& G. Forst., Char. Gen. Pl., ed. 2: 148, t. 74. 1776; G. Forst., De Plantis Magellanicis et Atlanticis Commentationes: 63, no. 170. Mar-Apr 1788 [as "Aitonia”]; Commentat. Soc. Regiae Sci. Gott. 9(1): 73, no. 170. 1789 [as "Aitonia"]. Ruppinia rupestris (J.R. Forst. \& G. Forst.) Sw., Meth. Musc.: 122. 1781. Plagiochasma rupestre (J.R. Forst. \& G. Forst.) Steph., Sp. Hepat. 1: 80. 1898.

Type: See the notes below.

Lectotype (designated here): Forster and Forster (1776): plate 74. Epitype (designated here): Madeira, Quinta do Bom Sucesso, 250-300 m, 12 May 1982, Sérgio \& Nóbrega 3873, LISU (LISU148993). Isoepitypes: BM (BM013409477), G (G00121308), PC (PC0771129 and PC0771134) [Bischler and Sérgio (1984) indicated that a duplicate of this specimen is also found in MADJ; however, it appears that this collection is no longer housed in this herbarium].

Notes: The original description by Forster and Forster (1776) did not provide details of where this species was recorded or collected. Likewise, there are no known original herbarium specimens. The protologue made reference to a single plate that was also published in the same work. Since this plate is an original material, it qualifies to serve as the lectotype. In this regard, the neotype proposed by Bischler and Sérgio (1984) is therefore rejected. As per the Shenzhen Code Art. 9.19(a), Bischler and Sérgio's choice is superseded. However, this plate (number 74) depicts six small fragments/plants, and in order to further clarify the identity of this taxon, our typification also includes an epitype, and in this regard, the specimen that Bischler and Sérgio (1984) designated previously as the neotype is chosen here.

Aytonia is a rejected name in favor of Plagiochasma Lehm. (see Turland et al. 2018). Forster and Forster (1776) coined the genus name Aytonia to honor "Joanne" (= John) Aiton. It is noted here that John Aiton (1711-1798) was the brother of William Aiton 1731-1793; the latter was the superintendent of the Kew Botanical Gardens ("Gardener to his Majesty") during 1759-1793. The remark by Forster and Forster (1776: "Huic Algae nomen dedimus a Joanne Ayton, Observatore curioso, Hortulano primario Regis Magnae Britanniae in horto Botanico Kewensi") indicates that the genus name Aytonia most likely honors William Aiton, and apparently, a typographical error was made by the Forsters regarding the honoree's first name. 
3. Borago tristis G. Forst., De Plantis Magellanicis et Atlanticis Commentationes: 41, no. 32. Mar-Apr 1788; Commentat. Soc. Regiae Sci. Gott. 9(1): 51, no. 32. 1789 (Boraginaceae).

Type: "S $\mathrm{S}^{\mathrm{ti}}$ Jacobi insula"

Lectotype (designated here): 1 Cape Verd Island: S $S^{\text {to }}$ Jago. JR \& G. Forster [label on back of the sheet]; 1 [label on narrow strip affixing specimen to the sheet], BM (BM13399018).

(=) Borago africana L., Sp. Pl. 1: 138. 1753. Pollichia africana (L.) Medik., Bot. Beobacht.: 248. 1783. Trichodesma africanum (L.) Sm. in A. Rees, Cycl. 36(1): Trichodesma no. 2. 1817. Boraginella africana (L.) Kuntze, Revis. Gen. Pl. 2: 435. 1891. Borraginoides africana (L.) Hiern, Cat. Afr. Pl. 1(3): 721. 1898. Trichodesma africanum (L.) Lehm., Pl. Asperif. Nucif.: 195. 1818, isonym. Trichodesma africanum R.Br., Prodr.: 496: 1810, nom. inval.

Type: "Habitat in Ætiopia."

Lectotype [designated by Kazmi (1971: 519)]: 188.4, LINN.

Notes: Borago tristis is a synonym of Trichodesma africanum, a species found both in Cabo Verde and mainland Africa. There is only one known collection of Borago tristis made by the Forsters, and it came from Cabo Verde. The collection matches the original description and it is part of a mixed sheet with two collections which is housed at BM. The back of this sheet has a label that helped us to identify Forster's specimen as it states: "1 Cape Verd Island: S ${ }^{\text {to }}$ Jago. JR \& G. Forster;" and this label matches the locality mentioned in the original description (island of Santiago). The specimen with barcode BM13399018 bears a number " 1 " on its mounting strip indicating that of the two specimens on the sheet, this is the collection made by the Forsters.

4. Epibaterium J.R. Forst. \& G. Forst., Char. Gen. Pl., ed. 2: 107. 1776, nom. rej. vs. Cocculus DC. 1817, nom. cons. (Menispermaceae)

Type: E. pendulum J.R. Forst. \& G. Forst., Char. Gen. Pl., ed. 2: 108, t. 54. 1776.

Epibaterium pendulum J.R. Forst. \& G. Forst., Char. Gen. Pl., ed. 2: 108. 1776; G. Forst., De Plantis Magellanicis et Atlanticis Commentationes: 59, no. 145. Mar-Apr 1788; Commentat. Soc. Regiae Sci. Gott. 9(1): 69, no. 145. 1789. Cebatha pendula (J.R. Forst. \& G. Forst.) Kuntze, Revis. Gen. Pl. 1: 9. 1891. Cocculus pendulus (J.R. Forst. \& G. Forst.) Diels in Engler, Pflanzenr. IV.94(Heft 46): 237. 1910. Cocculus epibaterium DC., Syst. Nat. 1: 530.1817 (“1818”), nom. superfl. \& illegit. for Epibaterium pendulum J.R. Forst. \& G. Forst.

Type: See the notes below.

Lectotype [designated by Troupin 1956: 10 (as "holotype")]: Cape Verd Islands. $S^{t}$ Jago Mesrs Forster [label on back of the sheet]; 1 [two labels on narrow strip affixing the specimen to the sheet], BM (BM001125013). Epitype (designated here): Cabo Verde, Porto de S. Francisco, Monte Ilhéu, 10-July-1993, M.C. Duarte 463, LISC (LISC128987). Isoepitypes: BM (BM013731571), A (A00969309).

Notes: Troupin (1956) selected a specimen housed at BM (BM001125013) to typify this name. The material that Troupin designated is mounted along with 
another collection (BM000554342) on a single sheet. A pencil line drawn on the sheet separates these two collections. BM001125013 consists of two sterile individuals; one of them with only a single leaf and the other with five leaves. Troupin annotated the specimen BM001125013 mentioning that it was collected by "Forster" in Cabo Verde. The second collection (BM000554342) was also labeled by Troupin, indicating that it was one of the specimens collected by G. Staunton in 1792, when he was on route to China with the Macartney embassy (Romeiras et al. 2014). A label placed on the back of the sheet concords with Troupin's annotations and it confirms that BM001125013 and BM000554342 were collected by the Forsters and Staunton, respectively. Troupin's (1956) citation of the BM001125013 specimen as the holotype is construed here as an inadvertent act of lectotypification as this name was typified before January 1, 2001.

As mentioned before, the lectotype is in poor condition as it has only five leaves. Nicolson and Fosberg (2004) mentioned only one specimen of this species collected by the Forsters, and it is housed in LIV (LIVCM/1909LBG.6431). We are not certain if this specimen is an actual duplicate of BM001125013; however, it is in even worse condition than the lectotype, with only six immature wrinkled leaves. Nicolson and Fosberg (2004) were apparently unaware of the BM specimen and of Troupin's type citation. It is noted here that the plate 54 (Forster and Forster 1775, 1776a, 1776b), mentioned in the protologue, shows one fruit and a few flower parts. In such a situation, although it may seem that the plate should be the preferred choice over the BM specimen for lectotypifying this name, it is not possible to supersede Troupin's inadvertent lectotype designation of an original material (see Art. 9.19), which is not in serious conflict with the protologue. As an alternative, we herewith designate an epitype to complement the sterile lectotype material. We selected a well-preserved specimen collected in Cabo Verde by one of us (MCD) that has well developed reproductive branches with many leaves. This specimen is housed in LISC (LISC128987) with duplicates in BM (BM013731571) and A (A00969309).

The name Epibaterium J.R. Forst. \& G. Forst. is rejected in favor of the conserved name Cocculus DC. (Turland et al. 2018).

5. Sida pannosa G. Forst., De Plantis Magellanicis et Atlanticis Commentationes: 52, no. 106. Mar-Apr 1788; Commentat. Soc. Regiae Sci. Gott. 9(1): 62, no. 106. 1789 (Malvaceae). Abutilon pannosum (G. Forst.) Schltdl., Bot. Zeit. 9: 828. 1851. Abutilon pannosum (G. Forst.) Webb, Fragm. Fl. Aethiop.-Aegypt.: 52. 1854, isonym.

Type: "S $\mathrm{C}$ Jacobi insula"

Lectotype [designated by Abedin (1979: 74, corrigenda [p. 109] (as "holotype”))]: 1 Cape Verd Islands. St Jago. Mssrs. Forster [label on back of the sheet]; 1 [label on narrow strip holding specimen to the sheet], BM (BM000802743).

Notes: There was some confusion regarding the typification of this name as the initial lectotype assigned by Abedin (1979), in his treatment of Abutilon for the Malvaceae volume of Flora of West Pakistan was incorrectly referred to a specimen collected in Senegal (no collector's name was mentioned) housed in MA. Subsequently, a single-page corrigenda was published for the Malvaceae volume of this 
flora (Nicolson and Fosberg 2004). This short addendum indicated that there was an error regarding the initial typification of Sida pannosa made by Abedin (1979). It appears that the sheet containing this corrigendum was sent as a separate document to those who already had the Malvaceae volume of Flora of West Pakistan; however, it seems that not all of the available copies of this volume have the corrigenda sheet. For instance, Fryxell (2002), in his revision pertinent to nomenclature of species of Abutilon, was not aware of the corrigendum. He mentioned: "TYPE: CAPE VERDE ISLANDS. Insula Sancti Jacobi, G. Forster s.n. (BM). -"described from Senegal (MA)" fide Abedin (1979a)." The corrigenda sheet does not have a page number or an author, but because the Malvaceae volume of Flora of West Pakistan was published by $S$. Abedin, it has been accepted that the corrigenda sheet was issued by Abedin in 1979 and numbered "109" (see Nicolson and Fosberg 2004). The specimen selected by Abedin (1979) for typification is housed in BM (BM000802743). Later, Abedin (1980) confirmed his selection of BM000802743 to typify Sida pannosa. This specimen is mounted on a mixed sheet with specimens collected by the Forsters and G. Staunton; the latter also collected from Cabo Verde (see above). However, Forsters's material has a number " 1 " written on the single strip affixed to the specimen, which matches the information written on the label found on the back of the specimen: "1 Cape Verd Islands. St Jago. Mssrs. Forster." The collecting site mentioned on this label concords with the locality indicated in the protologue (island of Santiago). Interestingly, BM000802743 was wrongly identified as the holotype of Sida pannosa by Abedin $(1979,1980)$. Here we correct this error and indicate that Abedin (1979) inadvertently lectotypified this name with this specimen.

6. Teucrium canescens G. Forst., De Plantis Magellanicis et Atlanticis Commentationes: 48, no. 106. Mar-Apr 1788; Commentat. Soc. Regiae Sci. Gott. 9(1): 58. 1789 (Lamiaceae).

Type: "Madeira, ad torrents"

Lectotype (designated here): Teucrium canescens (Forster) Habitat in Madeira, K (K001331973).

(=) Teucrium betonicifolium Jacq., Coll. 1: 145, t. 17-2, 1787 [as “betonicæfolium"] (Lamiaceae).

Teucrium maderense Lam. Encycl. 2(2): 692. 14 Apr 1788, nom. superfl. \& illegit. for T. betonicifolium Jacq.

Type: "Colitur in horto Cæsareo Schönbrunnensi"

Lectotype (designated here): Jacquin (1787): T. 17, Fig. 2 and illustration of single leaf without numeration depicted on bottom right side of plate 17. Epitype (designated here): Madeira: Entre Sao Antonio y Curral das Freiras, ca $900 \mathrm{~m}$. Laderas terrosas. Escaso. E. R. Sventenius 4.VII.1962. ORT (1057).

(=) Teucrium betonicum L'Hér., Stirp. Nov. 4: 83, t. 40. Mar-Apr 1788.

Type: "in Maderâ. Banks \& Solander. Masson."

Lectotype (designated here): MADEIRA 1768 BANKS \& SOLANDER [typed label], BM (BM013825662). Epitype (designated here): Madeira: Entre Sao Antonio y Curral das Freiras, ca. 900 m. Laderas terrosas. Escaso. E.R. Sventenius 4.VII.1962. ORT (1057). 
Notes: Jacquin (1787) described Teucrium betonicifolium based on the material raised in the Imperial Garden of Schönbrunn, Vienna, from the seeds sent from Madeira. There is evidence from Hooker's (1882: plate 6642) statement that in 1779 Francis Masson, official plant collector of the Royal Botanic Gardens, Kew, sent seeds of Macaronesian plants to Jacquin ("S. [Sonchus] jacquini is a native of rocky places in the "Laurel region" of the Island of Teneriffe, where it was discovered by Masson, a collector for the Royal Gardens of Kew, who in 1779 sent seeds to the Imperial Garden of Schœnbrun (Vienna), which produced the specimen well figured by Jacquin"). Between 1776 and 1779 Francis Masson visited the Azores, Canaries, and Madeira and sent plant material to Sir Joseph Banks (Francisco-Ortega et al. 2010). Therefore, it is likely that the plants of $T$. betonicifolium that Jacquin used to describe this species came originally from a shipment of seeds that he received from Masson. The protologue of this species made reference to "Tab. 17. Fig. 2.". Plate 17, also published by Jacquin (1787), depicted two figures (labeled as "Fig. 1" and "Fig. 2"), and also included an illustration of a single leaf with no labels. A shrub with hairy leaves is shown in "Fig. 1.", and it corresponds to a species also described by Jacquin (1787) as Arenaria multicaulis Jacq. (Caryophyllaceae). Based on the description of $T$. betonicifolium and the fact that the painting of this leaf does not match the hairy leaves of the plant illustrated in "Fig. 1," we consider this single leaf to also be part of "Fig. 2" and to belong to T. betonicifolium. Jacquin's herbarium is scattered in about 11 institutions, with the core housed in BM (Stafleu and Cowan 1979). These institutions were contacted and we received feedback from all of them except from AWH and CGE. Two sheets of this species are in Jacquin's herbarium in W (sheets 0078940 and 0078941). One of them, 0078941, was collected in Madeira, presumably by the Forsters (see below); therefore, we cannot consider this material as suitable for typification. The second sheet (0078940) has four fragments from two different collections that came from Kew Gardens and from "H-S.". The later refers to Hortus Schönbrunnensis ("H-S."), and therefore can be considered as original material to lectotypify Teucrium betonicifolium Jacq. The fragment mounted on the bottom left corner of 0078940 resembles the flowering branch illustrated by Jacquin (1787) that is part of the original description of this species. However, there are no labels that match the four fragments mounted on this sheet to the collections from Kew Gardens or from the Imperial Garden of Schönbrunn. As a result of these uncertainties regarding the material housed in $\mathrm{W}$, we selected the illustration indicated in the protologue as the lectotype of $T$. betonicifolium. Since this plate does not depict details of flowering parts we herewith designate an epitype and choose a specimen housed in ORT (1057) that was collected by E. R. Sventenius (1910-1973), founder of the Jardin Botánico Canario Viera y Clavijo. This specimen is also designated as the lectotype of $T$. betonicum (see below).

The description of Teucrium canescens indicates that it is a heterotypic synonym of $T$. betonicifolium. During our research, we found one specimen of this species collected by the Forsters in Madeira (K001331973) that was not reported by Nicolson and Fosberg (2004) and it was selected as the lectotype of this name. There is another specimen of this species housed in W (specimen 0078941), which 
apparently was also collected by them in Madeira. It does not have any annotation referring to the collectors but a label stating: "Teucrium canescens N. Sp. Madeira". According to records found in W it is likely that this is a duplicate of Forsters's original collection which was given to Jacquin filius during his visit to Göttingen, where many of G. Forster's specimens are housed. Eventually this material passed on to his father's herbarium at W (C. Bräeuchler pers. comm.).

Regarding Teucrium betonicum L'Hér., its original description (L'Héritier 1788) included one illustration (number XL) and made reference to collections made by Banks and Solander (with Cook during his first circumnavigation voyage) and by Masson in Madeira. Furthermore L'Héritier (1788) also cited this taxon as a synonym of the pre-Linnean polynomial Salvia major folio glauco serrato that was published by Sloane (1707). There are four sheets at BM that have original material associated to the protologue of this species. The first one is housed in the Sloane Herbarium and has one specimen with three sterile fragments (BM000589591). This collection matches the description and illustration of Sloane's (1707) polynomial. We did not chose this specimen as a lectotype because we preferred to select an actual herbarium collection listed by L'Héritier (1788). The second relevant specimen is also part of the historical collections of BM and it has two small leaves of this species that were collected by Banks and Solander in Madeira. They are mounted on a sheet that has mixed collections of at least six species, three of which are from Brazil and were not identified. The remaining three (Morella faya (Aiton) Wilbur, Myricaceae; Picconia excelsa (Aiton) DC, Oleaceae, and T. betonicifolium) were collected in Madeira. This sheet corresponds to folio 8 of a set of herbarium specimens that are bounded in a book that bears the title of Plants of Cook's First Voyage 1768-1771. Because this specimen has only two small leaves it was not selected as the lectotype. The third sheet with original material is in the General Herbarium at BM (barcode numbers BM000829332 and BM001025250). Based on the label information (on the back of this sheet), the sheet comprises three collections of T. betonicifolium. One is from Banks and Solander, the second was collected by Masson and the third made by an unknown collector in Madeira in 1763. The sheet has a total of six fragments and two of them are sterile. From the labels it is not clear which of these fragments can be assigned to the three collections. Given these uncertainties regarding the provenance of material mounted on this sheet, we chose not to select any of the material as lectotype. The specimen we designated as the lectotype, also housed in the General Herbarium, was mounted on the fourth sheet (BM013825662). It has three sterile fragments of a single specimen collected by Banks and Solander in Madeira. There are two labels, one of which is printed and states that it is a collection made in Madeira by Banks and Solander in 1768. The second label is handwritten and refers to Sloane's (1707) polynomial ("Salvia major folio glauco serrato Sloane. Hist. [illeg.] 17. t. $3 \mathrm{f} \mathrm{2").} \mathrm{Since} \mathrm{this} \mathrm{spe-}$ cimen does not depict flower details we have designated as an epitype a specimen housed in ORT (1057) which was also selected as the epitype of Teucrium betonicifolium (see above). The name T. betonicum L'Hér. has been used in most floristic studies of Madeira to refer to this species (e.g., Vieira 1992; Press 1994; Jardim and Francisco 2000; Menezes de Sequeira et al. 2008, 2012). Our nomenclature treat- 
ment establishes that $T$. betonicifolium Jacq. is a valid and legitimate name that was published earlier than T. betonicum L'Hér. and is therefore the correct name for this Madeiran endemic.

\section{ACKNOWLEDGEMENTS}

With this contribution, we join the organizers of FloraMac2018 to celebrate Cook's first visit to Madeira and his subsequent expeditions to Macaronesia. AS-G, JFO, MC, and MMR thank the organizing committee of FloraMac2018 for sponsoring their attendance to this international meeting. This is contribution 368 from the Tropical Biology Program of Florida International University. We dedicate this paper to the memory of Dan $\mathrm{H}$. Nicolson, as a mentor of KG he provided an inspiring career in plant taxonomy and nomenclature for many young taxonomists who sought his guidance and council at the National Museum of Natural History, Smithsonian Institution. Lourdes Rico helped to locate relevant type specimens in K. JFO thanks the College of Arts, Sciences and Education of FIU, the FIU Kimberly Green Latin American and Caribbean Center, and the FIU International Center for Tropical Botany for sponsoring a research visit to the Harvard University Herbaria. MMR would like to acknowledge the support provided by Fundação para a Ciência e Tecnologia (FCT) and Aga Khan Development Network (AKDN) under the project CVAgrobiodiversity/333111699. Our gratitude to Alan Franck (FIU) and Alfredo Reyes (ORT) who critically read an early draft of this article. Our searches for potential relevant specimens in Jacquin's collections were facilitated by Christian Bräuchler (W), Stephen Harris (OXF), Frank Hellwig (JE), Mats Hjertson (UPS), Geraldine Reid (LIV), Mark Spencer (LINN), Ari Taponen (H), and Robert Vogt (B). We are particularly grateful to Christian Bräuchler and Heimo Rainer (W) for their help interpreting Jacquin's collections housed in W; to César Garcia (LISU), Carlos A. Lobo (MADJ), and Germinal Rouhan (P) for helping us to locate type specimens of Aytonia rupestris in their home institutes; and to Alfredo Reyes for his help in locating the epitype of Teucrium betonicifolium and T. betonicum. We thank Marc Appelhans (GOET), Lotte Burkhardt (B), and Laurence J. Dorr (US), Stefan Dressler (F), Hans-Joachim Esser (M), and Susanne S. Renner (M) for their inputs in determining the date of G. Forster's publication. 


\section{AUTHORS' CONTRIBUTION}

Botanical history review: ASG, JFO, MCD, MMR

Nomenclature: JFO, KG

Location and taxonomic identification of relevant herbarium specimens: ASG, JFO, MAC, MCD, MMR

First draft: JFO, KG

Review and edition of the final draft: all authors.

ReCibido: abril de 2020; ACEPTADo: junio de 2020 


\section{REFERENCES}

Abedin, S. 1979. Malvaceae. In: Nasir, E. and Ali, S.I. (eds.) Flora of West Pakistan. Vol. 130. Karachi: University of Karachi, pp. 1-107, corrigenda.

Abedin, S. 1980. Abutilon muticum and Abutilon pannosum complex. Pak. J. Bot. 12: 43-48.

Barlass, T. 2018. We are all at sea describing Captain Cook with a rank he never had. The Sydney Morning Herald. [cited May 17, 2020]. Available from https://www.smh.com.au/national/we-are-all-a-sea-describing-captain.cook-with-a-rank-he-had-20180920-p5053j.html.

Bischler, H. and Sérgio, C. 1984. Un néotype pour Plagiochasma rupestre (J.R. et G. Forst.) Steph. Cryptogam. Bryol. Lichenol. 5: 173-174.

Bodi, K. 1959. Georg Forster: The 'Pacific expert' of eighteenth-century Germany. Historical Studies: Australia and New Zealand 8: 345-363.

Britten, J. 1904. R. Brown's list of Madeira Plants. J. Bot. 42: 1-8, 39-46, 175-182, 197-200.

DorR, L.J. and Nicolson, D.H. 2008. Taxonomic literature. A selective guide to botanical publications and collections with data, commentaries and types. Supplement vii: F-Frer. Regnum Veg. 149: 1-469.

Duarte, M.C. 1995. Menispermaceae. In: Paiva, J., Martins, E.S., Diniz, M.A., Moreira. I., Gomes, I. and Gomes, S. (eds.) Flora de Cabo Verde. Plantas vasculares. Vol. 4. Lisbon: Instituto de Investigação Científica Tropical and Praia, Instituto Nacional de Investigação e Desenvolvimento Agrário, pp. 1-9.

Earp, C. 2013. The date of publication of the Forsters' Characteres Generum Plantarum revisited. N. Z. J. Bot. 51: 252-263.

Forster, J.G.A. 1788. De plantis magellanicis et atlanticis commentationes [including De Fasciculus plantarum Magellanicarum: 1-33, t. 1-8. [\&] Plantae Atlanticae ex insulis Madeira St. Jacobi Adscensionis Stae Helenae et Fayay reportatae 34-62.]. Gottingen. 62 pp. [preprint of two articles subsequently published in Commentationes Societatis Regiae Scientiarum Gottingensis 9(1). 1789].

Forster, J.G.A. 1789. Plantae atlanticae ex insulis Madeira, St. Jacobi, Adcensionis, St. Helena et Fayal reportatae. Commentationes Societatis Regiae Scientiarum Gottingensis 9: 46-74.

Forster, J.R. and Forster, J.G.A. 1775. Characteres generum plantarum, quas in itinere ad insulas maris Australis, collegerunt, descripserunt, delinearunt, annis MDCCLXXII-MDCCLXXV. Ed. 1. London. $161 \mathrm{pp}$.

Forster, J.R. and Forster, J.G.A. 1776a. Characteres generum plantarum, quas in itinere ad insulas maris Australis, collegerunt, descripserunt, delinearunt, annis MDCCLXXII-MDCCLXXV. Ed. 2. London. 246 pp.

Forster, J.R. and Forster, J.G.A. 1776b. Characteres generum plantarum, quas in itinere ad insulas maris Australis, collegerunt, descripserunt, delinearunt, annis MDCCLXXII-MDCCLXXV. Ed. 3. London. 159 pp.

Francisco-Ortega, J., Santos-Guerra, A., Jarvis, C.E., Carine, M., Menezes de Sequeira, M. and Maunder, M. 2010. Early British collectors of the Macaronesian flora: From Sloane to Darwin. In: Knapp, S. and Williams, D.M. (eds.) Beyond cladistics: The branching of a paradigm. Berkeley: University of California Press, pp. 125-141. 
Francisco-Ortega, J., Santos-Guerra, A., Romeiras, M.M., Carine, M.A., Sánchez-Pinto, L., and Duarte, M.C. 2015. The botany of the three voyages of Captain Cook in Macaronesia: an introduction. Rev. Acad. Canar. Cienc. 27: 357-410.

Fryxell, P.A. 2002. An Abutilon nomenclator (Malvaceae). Lundellia 5: 79-118.

Grebrehiwet, M. 2000. Taxonomy, phylogeny and biogeography of Kickxia and Nanorrhinum (Scrophulariaceae). Nord. J. Bot. 20: 655-690.

Hooker, J.D. 1882. Sonchus jacquini. Native of the Canary Islands. Curtis's Botanical Magazine 108: Tab. 6642.

JaCquin, N.J. Von 1787. Collectanea at botanicam. Vol. 1. Wien: Ex officina Wappleriana 408 pp.

Jardim, R. and Francisco, D. 2000. Flora endémica da Madeira. Funchal: Múchia Publicações $338 \mathrm{pp}$.

Klopper, R.R., Chatelain, C., Bänninger, V., Habashi, C., Steyn, H.M., De Wet, B.C., Arnold, T.H., Gautier, L., Smith, G.F. and Spichiger, R. 2006. Checklist of the flowering plants of Sub-Saharan Africa. An index of accepted names and synonyms. South African Botanical Diversity Network Report No 42. Pretoria: SABONET 894 pp.

Kazmi, S.M.A. 1971. A revision of the Boraginaceae of West Pakistan and Kashmir. J. Arnold Arbor. 52: 486-522.

L'Héritier, C.L. 1788. Stirpes novae descriptionius et iconibus illustratae. Fasc. 4. Paris: Philippi-Dionysii Pierres 56 pp.

Martins, E.S. 1995. Boraginaceae. In: Paiva, J., Martins, E.S., Diniz, M.A., Moreira. I., Gomes, I. and Gomes, S. (eds.) Flora de Cabo Verde. Plantas vasculares. Vol. 74. Lisbon: Instituto de Investigação Científica Tropical and Praia: Instituto Nacional de Investigação e Desenvolvimento Agrário pp. 1-22.

Menezes de Sequeira, M., Capelo, J., Costa, J.C. and Jardim, R. 2008. Teucrium francoi M. Seq., Capelo, J.C. Costa \& R. Jardim, a new species of Teucrium gr. scorodonia (Lamiaceae) from Madeira. Bot. J. Linn. Soc. 156: 639-647.

Menezes de Sequeira, M., Espírito-Santo, D., Aguiar, C., Capelo, J. and Honrado, J. (Coordinators). 2012. Checklist da Flora de Portugal (Continental, Açores e Madeira). Portugal: Associação Lusitanica de Fitossociologia 74 pp.

Nicolson, D.H. 1998. First taxonomic assessment of George Forster's botanical artwork at GOET (Thuringia, Germany). Taxon 47: 581-592.

Nicolson, D.H. and Fosberg, F.R. 2004. The Forsters and the botany of the Second Cook Expedition (1772-1775). Second edition. Regnum Veg. 139: 1-759.

Obeyesenere, G. 1992. The apotheosis of Captain Cook. European mythmaking in the Pacific. Princeton: Princeton University Press 251 pp.

Press J. 1994. Teucrium L. In: Press, J. and Short, M.J. (eds.) Flora of Madeira. London: Natural History Museum pp. 281-283.

Romeiras, M.M., Duarte, M.C., Santos-Guerra, A., Carine, M. and Francisco-Ortega, J. 2014. Botanical exploration of the Cape Verde Islands: From the pre-Linnaean records and collections to the late 18th century floristic accounts and expeditions. Taxon 30: 625-640.

Sérgio, C., Sim-Sim, M. and Carvalho, M. 2006. Annotated catalogue of Madeira bryophytes. Boletim do Museu Municipal do Funchal (História Natural) Suplemento 10: 1-163. 
Sloane, H. 1707. A voyage to the islands Madera, Barbados, Nieves, S. Christophers and Jamaica. Vol. 1. London: British Museum 592 pp.

Stafleu, F.A. and Cowan, R.S. 1976. Taxonomic literature. A selective guide to botanical publications and collections with data, commentaries and types. Ed. 2. Vol. I: A - G. Regnum Veg. 94: 1-1136.

Stafleu, F.A. and Cowan, R.S. 1979. Taxonomic literature. A selective guide to botanical publications and collections with data, commentaries and types. Ed. 2. Vol. II: H - Le. Regnum Veg. 98: 1-991.

Sutton, D.A. 1988. A revision of the tribe Antirrhineae. London: British Museum (Natural History) $575 \mathrm{pp}$.

Thiers, B. 2019. Index Herbariorum: A global directory of public herbaria and associated staff. New York Botanical Garden's Virtual Herbarium. Available from: http://sweetgum.nybg.org/ science/ih/.

Troupin, G. 1956. Menispermaceae. In: Turrill, W.B. and Milne-Redhead, E. (eds.) Flora of Tropical East Africa. London: Secretary of State for the Colonies. Crown Agents for Oversea Governments and Administrations, pp. 1-32.

Turland, N.J., Wiersema, J.H., Barrie, F.R., Greuter, W., Hawksworth, D.L., Herendeen, P.S., Knapp, S., Kusber, W.-H., Li, D.-Z., Marhold, K., May, T.W., McNeill, J., Monro, A.M., Prado, J., Price, M.J. and Smith, G.F. (Editors). 2018. International Code of Nomenclature for algae, fungi, and plants (Shenzhen Code) adopted by the Nineteenth International Botanical Congress Shenzhen, China, July 2017. Regnum Veg. 159: 1-254.

VieIra, R. 1992. Flora da Madeira. O interesse das plantas endémicas macaronésicas. Lisbon: Serviço Nacional de Parques, Reservas e Conservação da Natureza [Colecção Natureza e Paisagem, vol. 11] 155 pp. 
